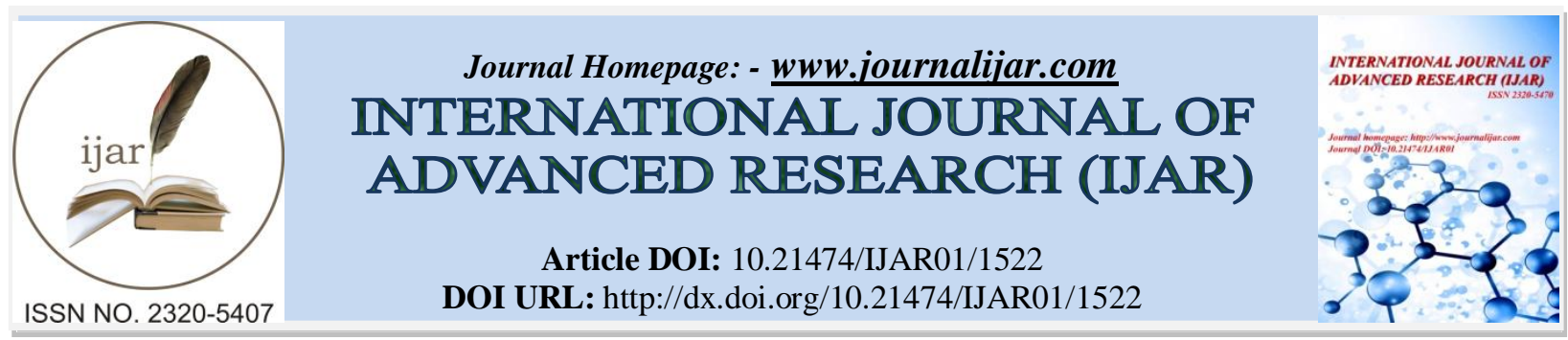

RESEARCH ARTICLE

\title{
SYNTHESIS OF 4-HYDROXY-2-PHENYL 6/7 SUBSTITUTED QUINOLINES AND ASSESMENT OF THEIR ANTIBACTERIAL ACTIVITY.
}

Farida P. Minocheherhomji

Department of Microbiology, B. P. Baria Science Institute, NAVSARI - 396445, Gujarat, India.

\section{Manuscript Info}

Manuscript History

Received: 15 July 2016

Final Accepted: 19 August 2016

Published: September 2016

Key words:-

Quinoline compounds, Antibacterial

activity, 4-hydroxy-2-phenyl 6/7

substituted quinolines

\section{Abstract}

Industrial application of disperse dyes is based on numerous chromophore systems. Approximately $60 \%$ of the available disperse dyes are azo based, and $25 \%$ are anthraquinone based. Remainders of the dyes are quinaphthalene, methine, napthalimide, naphthaquinone and nitro based. The development in azo dyestuff chemistry is mainly to make in-roads into the traditional anthraquinone area. Development in azo disperse dyes over five decades have made it possible to produce a full range of colours with improved dyeing performance with better fastness properties, and also having therapeutic values. Synthesis and application of azo dyes derived from quinoline system have also been reported earlier. So this study is carried out to encourage the synthesis of some new azo disperse dyes like 4hydroxy-2-phenyl 6/7 substituted quinolines along with their antibacterial activity.

Copy Right, IJAR, 2016,. All rights reserved.

\section{Introduction:-}

The versatility of azo class of dyes is due to the fact that azo compounds can be made and any dye azotized aromatic amine can be coupled with stable nucleophillic unsaturated system to give a colored azo product. Azo dyes have accounted for more than half of the total available disperse dyes, virtually covering a major part of the color spectrum. Heterocyclic diazo coupling components have played a prominent role in azo dye chemistry.

Heterocyclic coupling components give heterocyclic azo disperse dyes with color ranging from yellow to dark red. The compactness and extension of conjugation in the structures of heterocyclic compounds are important for the disperse dyes derived from them ${ }^{7}$. Over the past few decades, it has been found that only a few heterocyclic based coupling components attained the brilliance of the azo benzene dyes, as well as anthraquinone dyes with better therapeutic values ${ }^{6}$.

Synthesis and application of disperse dyes derived from quinoline and quinolinoquinazoline moieties have been reported earlier ${ }^{1,2}$. In a view of encouraging the reports of the technical application of heterocyclic dyes, it was thought necessary to undertake the synthesis and also study the antimicrobial property of mono azo disperse dyes based on 2-phenyl-4-hydroxy-6/7-substituted quinoline derivatives. The monoazo disperse dyes of the following types were prepared. 
<smiles>[R]Cc1cccc2nc(C(C)C)c(N=N)c(O)c12</smiles>

Where, $\mathrm{R}:$ 6- $\mathrm{CH}_{3}, 6-\mathrm{Cl}, 6-\mathrm{OCH}_{3}, 6-\mathrm{OC}_{2} \mathrm{H}_{5}, 6-\mathrm{NO}_{2}, 7-\mathrm{Cl}$

$\mathrm{R}^{\prime}$ : Various diazo components

Azo compounds are known for their antibacterial properties. The synthesis of substituted 4-hydroxy-3-(substituted aryl azo)-2-phenyl quinolines were carried out to find whether they show an additional antibacterial effect or mutually imposing effect, or whether partial activity is retained ${ }^{\mathbf{1 6}}$. The bacteria selected for the study of antibacterial activity by Disc Diffusion Technique ${ }^{\mathbf{1 0}}$ were Escherichia coli, Salmonella paratyphi B, Bacillus subtilis and Staphylococcus aureus. Disperse dyes gave the most satisfactory result due to their simple application methods ${ }^{5,15}$.

\section{Materials and Methods:-}

4-Hydroxy-2-phenyl-6/7- substituted quinoline can be synthesized by the following reaction.

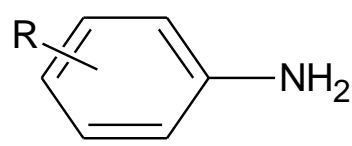

Aryl amine

\section{$+\mathrm{C}_{6} \mathrm{H}_{5} \mathrm{COCH}_{2} \mathrm{COOC}_{2} \mathrm{H}_{5}$}

Ethyl benzoyl acetate

$\downarrow$

A drop of concentrated $\mathrm{HCl}$ refluxed in boiling toluene for 8 hours<smiles>[R]c1ccc(NC(=CC(=O)OCC)c2ccccc2)cc1</smiles>

Anil-anilide<smiles>[R]CCc1cccc2nc(C(C)(C)C)cc(O)c12</smiles>

4-Hydroxy-2-phenyl-6/7- substituted quinoline

Where, R: 6- $\mathrm{CH}_{3}, 6-\mathrm{Cl}, 6-\mathrm{OCH}_{3}, 6-\mathrm{OC}_{2} \mathrm{H}_{5}, 6-\mathrm{NO}_{2}, 7-\mathrm{Cl}$

A mixture of aryl amine (based component) 0.04 Mole and ethyl benzoylacetate 0.02 Mole with a drop of concentrated $\mathrm{HCl}$ was refluxed in $30 \mathrm{ml}$ of boiling toluene for 8 hours, and the solvent was evaporated living a residue which was directly cyclised by Poly Phosphoric Acid (PPA) ${ }^{11}$.

\section{Preparation of PPA:-}

It is prepared by dissolving 30 grams Phosphorus pentoxide in $18 \mathrm{ml}$ of ortho-phosphoric acid (d: 1.75). The mixture was heated at $95-100{ }^{\circ} \mathrm{C}$ for 30 minutes. The scum was removed, and the clear solution thus obtained was used for cyclisation experiment.

\section{Cyclisation:-}

The above crude anil-anilide was mixed with freshly prepare PPA and stirred well for some time with temperature raised to $120^{\circ} \mathrm{C}$. The mixture was kept in a dessicator over night. Next day, the temperature was slowly raised step 
wise by $10{ }^{\circ} \mathrm{C}$ until it reached $155{ }^{\circ} \mathrm{C}$ for 90 minutes. This treatment helps in getting clean product with a high yield. The reaction mass was decomposed with crushed ice and neutralized with a mixed solution of Sodium and Ammonium hydroxide, maintaining it slightly on the acidic side. The product was filtered, washed with water, and dried. Different yields were obtained for different compounds have different melting points as shown in Table 1.

The product was purified by alkali and acid treatment, and crystallized using aqueous ethanol. These crystals exhibited different melting points. In case of 4-hydroxy-7-chloro-2-phenyl quinoline, the melting point (M.P.) range is large. So it is presumed to be a mixture of isomers. The isomers can be separated by heating 4 grams of the product with $80 \mathrm{ml}$ alcohol. The hot solution is filtered, leaving a residue of 4-hydroxy-7-chloro-2-phenyl quinoline.

\section{Antibacterial Activity:-}

The antibacterial activity of the compounds was tested by the Standard Disc Diffusion Method developed by Bauer ${ }^{\mathbf{1 0}}$ using Muller Hintons Agar medium ${ }^{4}$. All the compounds were dissolved in Dimethyl formamide (DMF). Proper drug controls were used. 2-phenyl-4 hydroxy-6,7 substituted quinoline derivatives, and mono azo disperse dyes based on 2-phenyl- 4-hydroxy-6,7 substituted quinoline derivatives were taken at a concentration of $50 \mathrm{mg} / \mathrm{ml}$ for assessing their antibacterial activity. The compound diffused into the medium produced a concentration gradient. After a prefixed incubation period, the zone of inhibition was measured in $\mathrm{mm}$. The test cultures used for the purpose are:

\section{* Bacillus subtilis \\ - Staphylococcus aureus \\ * Escherichia coli \\ * Salmonella paratyphi B}

The inoculum was standardized at $1.5 \times 10^{8} \mathrm{CFU} / \mathrm{ml}$ by comparing with turbidity standard ( 0.5 \Mac Farland tube).The plates were inoculated by dipping a sterile swab into the inoculum. Excess of the inoculum was removed by pressing and rotating the swab firmly against the side of the tube above the level of the liquid.

The swab was streaked all over the surface of the medium thrice rotating the plate through an angle of 60 degrees after each application. Finally, the swab was passed round the edge of the agar surface. The inoculum was dried for a few minutes at room temperature. The antibiotic discs were placed on the inoculated plates using a pair of sterile forceps. A sterile needle tip was used to place the antibiotic disc on the plate. The plates were then kept in an incubator maintained at $35^{\circ} \mathrm{C}$ for 24 hours. Next day, the diameter of each zone of inhibition was measured and recorded in $\mathrm{mm}$.

\section{Results and Discussion:-}

Table 1:- Synthesis of 4-Hydroxy-2-phenyl-6/7- Substituted Quinolines using different Aryl amine based components

\begin{tabular}{|l|l|l|l|c|c|}
\hline Sr. & \multicolumn{1}{|c|}{$\begin{array}{c}\text { Name of the } \\
\text { Compound }\end{array}$} & \multicolumn{1}{|c|}{ Anil-anilide Formed } & \multicolumn{1}{|c|}{$\begin{array}{c}\text { Aryl Amine } \\
\text { based } \\
\text { component }\end{array}$} & $\begin{array}{c}\text { Percentage } \\
\text { Product Yield } \\
\text { After } \\
\text { Cyclisation }\end{array}$ & $\begin{array}{c}\text { Melting } \\
\text { Point } \\
{ }^{\circ} \mathbf{C}\end{array}$ \\
\hline 1 & $\begin{array}{l}\text { 4-hydroxy-6-methyl-2- } \\
\text { phenyl quinoline }\end{array}$ & $\beta$-p-toluidinocinnamo-p-toluidide & p-toluidine & 76 & $294-295$ \\
\hline 2 & $\begin{array}{l}\text { 4-hydroxy-6-chloro-2- } \\
\text { phenyl quinoline }\end{array}$ & $\begin{array}{l}\beta \text {-p-chloronilinocinnamo-p- } \\
\text { chloroanilide }\end{array}$ & $\begin{array}{l}\text { 6-chloro } \\
\text { aniline }\end{array}$ & 70 & $350-351$ \\
\hline 3 & $\begin{array}{l}\text { 4-hydroxy-6-methoxy- } \\
\text { 2-phenyl quinoline }\end{array}$ & $\begin{array}{l}\beta \text {-p-methoxyanilinocinnamo-p- } \\
\text { methoxyanilide }\end{array}$ & p-anisidine & 85 & 288 \\
\hline 4 & $\begin{array}{l}\text { 4-hydroxy-6-ethoxy-2- } \\
\text { phenyl quinoline }\end{array}$ & $\begin{array}{l}\beta \text {-p-ethoxyanilinocinnamo-p- } \\
\text { ethoxyanilide }\end{array}$ & P-phenetidine & 78 & 284 \\
\hline 5 & $\begin{array}{l}\text { 4-hydroxy-6-nitro-2- } \\
\text { phenyl quinoline }\end{array}$ & $\begin{array}{l}\beta-p-\text {-nitroanilinocinnamo-p- } \\
\text { nitroanilide }\end{array}$ & $\begin{array}{l}\text { 4-nitro } \\
\text { aniline }\end{array}$ & 50 & $328-329$ \\
\hline 6 & $\begin{array}{l}\text { 4-hydroxy-7-chloro-2- } \\
\text { phenyl quinoline }\end{array}$ & $\begin{array}{l}\beta-\text {-m-chloroanilinocinnamo-m- } \\
\text { chloroanilide }\end{array}$ & $\begin{array}{l}\text { m-chloro } \\
\text { aniline }\end{array}$ & 80 & $245-268$ \\
\hline
\end{tabular}


The newly synthesised compounds with different yields as well as varying melting points can be further characterized using Infra red spectroscopy and NMR. The same was studied on 2-chloro-6-methyl-quinoline hydrazone derivatives ${ }^{3}$.

Table 2:- Antibacterial Activity of 4-Hydroxy-2-phenyl-6/7- Substituted Quinolines.

\begin{tabular}{|c|c|c|c|c|c|}
\hline \multirow[b]{2}{*}{$\begin{array}{c}\mathbf{S r} \\
\#\end{array}$} & \multirow[b]{2}{*}{ Name of the Compound } & \multicolumn{4}{|c|}{ Zone of Inhibition, in $\mathrm{mm}$} \\
\hline & & $\begin{array}{l}\text { Bacillus } \\
\text { subtilis }\end{array}$ & $\begin{array}{c}\text { Staphylococcus } \\
\text { aureus }\end{array}$ & $\begin{array}{l}\text { Escherichia } \\
\text { coli }\end{array}$ & $\begin{array}{l}\text { Salmonella } \\
\text { paratyphi } B\end{array}$ \\
\hline & DMF Solvent (Control) & Nil & Nil & Nil & Nil \\
\hline 1 & $\begin{array}{l}\text { 4-hydroxy-6-methyl-2-phenyl } \\
\text { quinoline }\end{array}$ & Nil & Nil & 12 & 12 \\
\hline 2 & $\begin{array}{l}\text { 4-hydroxy-6-chloro-2-phenyl } \\
\text { quinoline }\end{array}$ & Nil & Nil & Nil & Nil \\
\hline 3 & $\begin{array}{l}\text { 4-hydroxy-6-methoxy-2-phenyl } \\
\text { quinoline }\end{array}$ & 09 & 10 & 10 & 13 \\
\hline 4 & $\begin{array}{l}\text { 4-hydroxy-6-ethoxy-2-phenyl } \\
\text { quinoline }\end{array}$ & Nil & 11 & 09 & Nil \\
\hline 5 & $\begin{array}{l}\text { 4-hydroxy-6-nitro-2-phenyl } \\
\text { quinoline }\end{array}$ & Nil & 25 & Nil & Nil \\
\hline 6 & $\begin{array}{l}\text { 4-hydroxy-7-chloro-2-phenyl } \\
\text { quinoline }\end{array}$ & 09 & 12 & Nil & Nil \\
\hline
\end{tabular}

Each compound synthesized had its specific maximum and minimum bacteriostatic potential depending upon the specific species. Similar results as those obtained were also found in the compound 2,4-dihydroxy-6-methyl quinoline. The antibacterial effect was equivalent to the current study ${ }^{\mathbf{1 3}, \mathbf{1 4}}$. The quinoline moiety with a methoxy substituent at position 6 was found to be the most effective ${ }^{8}$.

The results of the antibacterial activity of different compounds are summarized as follows:

1. 4-hydroxy-6-methoxy-2-phenyl quinoline ( $\mathrm{Sr \#} \mathrm{3)} \mathrm{was} \mathrm{active} \mathrm{against} \mathrm{both} \mathrm{Gram} \mathrm{positive} \mathrm{and} \mathrm{Gram} \mathrm{negative}$ bacteria used as test organisms. Maximum antibacterial activity was shown by this compound.

2. 4-hydroxy-6-chloro-2-phenyl quinoline ( $\mathrm{Sr} \# 2$ ) did not exhibit any antibacterial activity against both Gram positive and Gram negative bacteria.

3. 4-hydroxy-6-methyl-2-phenyl quinoline (Sr\# 1), 4-hydroxy-6-ethoxy-2-phenyl quinoline (Sr\# 4) and 4hydroxy-7-chloro-2-phenyl quinoline ( $\mathrm{Sr \#} \mathrm{6)} \mathrm{exhibited} \mathrm{moderate} \mathrm{to} \mathrm{good} \mathrm{antibacterial} \mathrm{activity} \mathrm{against} \mathrm{both}$ Gram positive and Gram negative bacteria.

4. 4-hydroxy-6-nitro-2-phenyl quinoline (Sr\# 5) exhibited highest antibacterial activity against only one Gram positive bacteria Staphylococcus aureus; whereas the same compound did not have any antibacterial effect on other Gram positive and Gram negative bacteria.

This implies that each compound acts differently over specific species of bacteria as far as its bacteriostatic potential and effect is concerned. These compounds can be subjected to evaluate their free radical scavenging activity by DPPH model in another study ${ }^{7,13}$. These compounds need to be checked for their Anti-HIV properties, Analgesic activity, Antirheumatoid and Antitubercle activity $9,12,17$.

\section{Conclusion:-}

From the above results it can be concluded that 4-hydroxy-6-methoxy-2-phenyl quinoline (Sr\# 3), if coupled with other coupling components, would exhibit better antibacterial properties than the rest of the compounds synthesized.

\section{Acknowledgement:-}

I hereby express my sincere gratitude to my friend and colleague Dr. (Mrs.) Kirtida K. Vaidya, Associate-Professor (Chemistry), B. P. Baria Science Institute, Navsari for helping me in this research. 


\section{Bibliography:-}

1. Abdel-Mohsen SA (2005); Synthesis, reactions and antimicrobial activity of 2-amino-4- (8-quinolinol-5-yl)-1-(ptolyl)-pyrrole-3-carbonitrile; Bull Korean Chem Soc, 26: 719-26.

2. Abou-DobaraI MI, El-Sonbati AZ, Diab MA, El-Bindary AA, Morgan SM (2014); Thermal properties, antimicrobial activity of azo complexes and ultra structure study of some affected bacteria; J Microb Biochem Technology; Available from: http://www.dx.doi. org/10.4172/1948-5948.S3-006.

3. Bawa S, Kumar S, Drabu S, Kumar R (2009); Synthesis and antimicrobial activity of 2-chloro-6-methylquinoline hydrazone derivatives; J of Pharmacy and Bioallied Sci, 1(1): 27-31.

4. Champaneri DY, Mehta AG (2016); Studies on antibacterial activity of monoazo disperse dyes based on 2,4Dihydroxy-6-methyl quinoline; Inter J of Adv Tech in Engg and Sci, 4(1) 51-57.

5. Chinnagiri TK, Keshavayya J, Rajesh NT, Peethambar KS, Ali SA (2013); Synthesis, characterization, and biological activity of 5-Phenyl-1, 3, 4-thiadiazole-2-amine incorporated azo dye derivatives; Organ Chem Int,1-7.

6. Desai P, Parekh D (2014); Metal Complexation of Novel Organic Ligands; Laxmi Book publication, Solapur, India, 115.

7. Keerthi kumar CT, Keshavayya J (2013); Synthesis, characterization and biological activity of hetereo cyclic azo dyes derived from 2-Amino-benzothiazole; Inter J of Pharm and Pharmaceutical Sci, 5 296-301.

8. Kharb R, HardeepKaur (2013); Therapeutic significance of Quinoline derivatives as antimicrobial agents; Int Res J Pharm, 4(3) 63-69.

9. Ningappa MB, Dinesh R, Srinivas L (2008); Antioxidant and free radical scavenging activities of polyphenolenriched curry leaf extract (Murraya koenigii L.); Food Chem., 106 720-28.

10. Prescott, Harley and Klein; Microbiology, $5^{\text {th }}$ Edition; McGraw Hill Publication, Ch. 35, 806

11. Reddy GV, Kanth SR, Maitraie D, Narsaiah B, Rao PS, Kishore KH (2009); Design, synthesis, structure-activity relationship and antibacterial activity series of novel imidazo fused quinolone carboxamides; Eur J Med Chem, 44: 1570-78.

12. Rohini RM, Kalpana Devi, Devi S (2015); Synthesis of novel azo chalcone derivatives for antitubericular, anti inflammatory and antioxidant activity; Der Pharm Chem., 7(1): 77-83

13. Sahoo J, Paidesetty SK (2015); Antimicrobial, analgesic, antioxidant and in silico study of synthesized salicylic acid congeners and their structural interpretation; Egypt J Basic Appl Sci., 2: 268-80.

14. Sahoo J, Paidesetty SK (2015); Biological evaluation and spectral characterization of 4-hydroxy coumarin analogues; J Taibah Univ Med Sci., 10 306-19.

15. Sahoo J, Paidesetty SK (2016); Medicinal interest of azo based organic compounds; Asian Journal of Pharmaceutical and Clinical Research, 9.

16. Shridhar AH, Keshavayya J, Peethambar SK, Hoskeri HJ (2012); Synthesis and biological activities of Bis alkyl 1, 3, 4-oxadiazole incorporated azo dye derivatives; Arab J Chem.; Available from: http://www.dx.doi. org/10.1016/j.arabjc

17. Tonelli M, Vazzana I, Tasso B, Boido V, Sparatore F, Fermeglia M, (2009); Antiviral and cytotoxic activities of aminoarylazo compounds and aryltriazene derivatives; Bioorg Med Chem 17(13): 4425-4440. 